\title{
In-Situ Measurement of In-Plane Temperature Distribution in a Single-Cell Polymer Electrolyte Fuel Cell Using Thermograph
}

\author{
(1st Report: Impacts of Gas Flow Rate at Inlet and Gas \\ Channel Pitch of Separator on In-Plane Temperature \\ Distribution and Power Generation Performance)*
}

\author{
Akira NISHIMURA**, Kenichi SHIBUYA**, Atsushi MORIMOTO**, \\ Shigeki TANAKA**, Masafumi HIROTA**, Yoshihiro NAKAMURA***, \\ Masashi KOJIMA*** and Masahiko NARITA*** \\ ${ }^{* *}$ Mie University, \\ 1577 Kurimamachiya-cho, Tsu, Mie Pref., 514-8507, Japan \\ E-mail: nisimura@mach.mie-u.ac.jp \\ *** Toho gas Co., LTD., \\ 507-2 Shinpo-machi, Tokai, Aichi Pref., 476-8501, Japan
}

\begin{abstract}
To clarify the mechanism of combined phenomena of heat, mass and electric charge transfers in a single-cell polymer electrolyte fuel cell (PEFC), it is necessary to measure in-plane temperature distribution of a single-cell PEFC when it is run, i.e., generating power. The measurement by thermograph assists to investigate the influence of gas flow rate at inlet and gas channel pitch of separator on in-plane temperature distribution and power generation performance. As a result, the higher temperature region is observed near the outlet of cell when the excess ratio of gas flow is set due to the convective heat transfer by excess oxygen flow in gas channel at the cathode. When the gas flow is set at stoichiometric, in-plane temperature distribution becomes even and high power generation performance can be achieved. The other observation is that the total voltage is increased and temperature in observation area is dropped with decreasing gas channel pitch of separator irrespective of gas flow rate.
\end{abstract}

Key words: PEFC, Heat Transfer, Energy Conversion, Thermograph, In Situ Measurement, In Plane Temperature Distribution, Gas Flow Rate, Gas Channel Pitch

${ }^{\star}$ Received 25 Oct., 2010 (No. T1-09-0692) Japanese Original : Trans. Jpn. Soc. Mech. Eng., Vol.76, No.762, B (2010), pp.342-351 (Received 23 July, 2009) [DOI: 10.1299/jee.6.1]

Copyright () 2011 by JSME

\section{Introduction}

The current trends in developing Polymer Electrolyte Fuel Cell (PEFC) are mainly: (1) durability enhancement, (2) improvement of power generation efficiency, (3) reduction of cost. Although the even and high power generation on the reaction surface of single cell of PEFC is required essentially as a characteristic of power generator, there is few studies that have investigated the ways of operation control and parts design of PEFC to realize optimum power generation ${ }^{(1,2)}$. Uneven in-plane distribution of current, temperature and water in the cell during power generation causes the degradation of power generation performance ${ }^{(3-9)}$. Therefore, if the power generation on the reaction surface is carried out 
uniformly, the prevention of degradation as well as improvement of power generation performance can be expected. Consequently, it is very effective to control the power generation operation and design the parts of cell for the even in-plane distribution of gas, water and temperature on the reaction surface of cell.

In this study, the dominant factor of combined mass, heat and electric charge transfers in PEFC is investigated at first to propose the way to control power generation operation and design the parts of cell for even in-plane distribution of gas, water and temperature on the reaction surface of cell. Especially, this study focuses on the temperature distribution in the cell. Due to local temperature rise and uneven in-plane temperature distribution, thermal decomposition and thermal stress rupture of polymer electrolyte membrane (PEM) are occurred, resulting in degradation of $\operatorname{PEM}^{(7,10,11)}$.

In addition, according to the following Nernst relationship, it is important to control the temperature and the relative humidity in PEM for achieving the high power generation performance of $\operatorname{PEFC}^{(12,13)}$.

$$
E=E^{0}+\frac{R T}{2 F} \ln \left(\frac{a_{\mathrm{H}_{2}} \cdot a_{\mathrm{O}_{2}}{ }^{\frac{1}{2}}}{a_{\mathrm{H}_{2} \mathrm{O}}}\right)
$$

Moreover, the phase of produced water moving from the reaction surface to gas diffusion layer (GDL) or gas channel of separator is affected by the saturation vapor pressure and partial pressure of water where the water exists. If the partial pressure of water was over the saturation vapor pressure which is determined by the temperature where the water exists, the water would condense. If too much water exists in GDL and gas channel of separator, the flooding and plugging would occur, resulting in reduction of power generation performance. Consequently, controlling the temperature distribution in the single cell of PEFC is necessary for not only the management of water behavior and power generation ${ }^{(7,14)}$ but also the durability enhancement and improvement of electrical efficiency of PEFC.

Nondestructive in-situ temperature measurement by thermograph is an effective procedure for measuring the temperature distribution in PEFC since the impact of measurement on the power generation performance is much less compared with the direct and destructive temperature measurement procedure like thermocouple. Although there were many studies that investigated the production and distribution of condensed water in the cell of $\operatorname{PEFC}^{(9,12,15-23)}$, the number of studies on in-situ temperature measurement was much less. Furthermore, a transparency material like silicon glass was inserted into the single cell to observe the inside of cell ${ }^{(1,7,13,24,25)}$ in previous studies. There was no report verifying the impact of absorbing infrared rays by the water attached on the glass which seemed to cause the measurement error of thermograph. In addition, the measurement error was caused by the change in tightening pressure of single cell since the transparency material was inserted in the cell ${ }^{(1,24)}$. Therefore, the improvement of in-plane temperature distribution measurement by thermograph is necessary to understand the mass and heat transfer phenomena in the cell of PEFC accurately. In previous studies, the measured temperature range set from $268 \mathrm{~K}$ to $333 \mathrm{~K}$ to observe the condensation or freeze of water $^{(1,7,13,24,25)}$ was lower than the actual power generation operation temperature of PEFC, which is normally in range from $343 \mathrm{~K}$ to $353 \mathrm{~K}$.

The goal of this study is as follows: (1) to measure the in-plane temperature distribution in single cell of PEFC more accurately by the in-situ measurement using thermograph and observation window, (2) to investigate the impact of power generation operation condition and separator structure on in-plane temperature distribution in the single cell, (3) to clarify the factors causing the uneven in-plane temperature distribution.

To achieve these goals, a window to observe the in-plane temperature distribution was 
made at the cathode side of single cell of PEFC as shown in Fig.1 in this study. The end block, the current collector and the hot water passage plate at cathode side were bored, resulting that the observation area was the backside of separator to gas channel contacting GDL. Since the observation area is a flat side of separator and the phenomena in MEA and GDL are not changed, there is no absorption of infrared rays by the water during the temperature measurement by thermograph. Moreover, since no foreign material like glass is inserted into the cell, the measurement error caused by the change in tightening pressure of single cell or gas leak can be avoided.

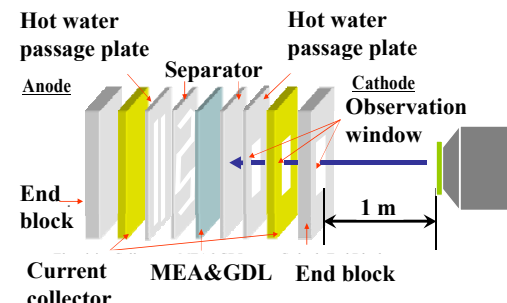
collector

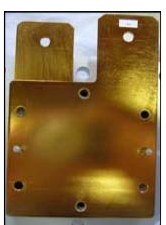

Current collecto

(L: before boring ; R: after boring)

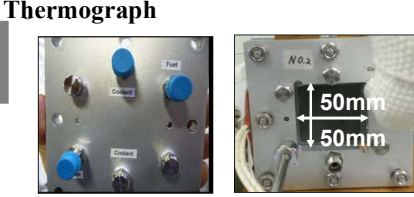

End block

(L: before boring ; R : after boring)

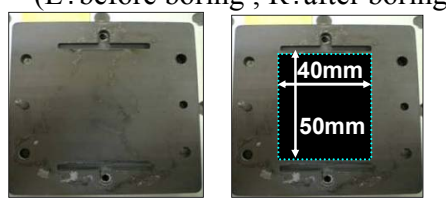

Hot water passage plate

(L:before boring ; R: after boring)

Fig.1 Single cell of PEFC with observation window

To measure the in-plane temperature distribution caused by reaction heat accurately, the current density is set at $0.80 \mathrm{~A} / \mathrm{cm}^{2}$ that is comparatively high. Generally speaking, it is necessary for a single cell to be operated with an external heat supplied to maintain the temperature at the level that power generation requires. However, under the high current density condition, the power generation can be maintained by reaction heat without external heat supply. The investigation of in-plane temperature distribution under the high current density condition is important since the voltage drop by flooding at cathode side and dry-out at anode side by high reaction heat may occur under this condition ${ }^{(8,26)}$.

Moreover, the impact of gas channel pitch, which is the interval of gas channel and rib of separator, on in-plane temperature distribution is investigated in this study. Since it was reported that the distribution of produced water and power generation performance were changed with changing width of gas channel and rib of separator contacting $\operatorname{GDL}^{(29,30)}$, the impact of width of gas channel and rib of separator on in-plane distribution of gas concentration, produced water, temperature and current density seems large. Although there are many types of developing separators ${ }^{(31-35)}$, the serpentine type which is a standard separator type is selected in this study. Since it is thought that the enhancement of power generation performance by simple improvement of cell structure or optimization of power generation operation condition is an effective way to prevail PEFC, the serpentine type separator whose gas channel pitch size can be manufactured by simple cutting work is selected.

In the present study, the gas channel pitch is changed by $0.5 \mathrm{~mm}, 1.0 \mathrm{~mm}$ and $2.5 \mathrm{~mm}$, while the width ratio of gas channel to rib is set at 1.0. In the power generation experiment, the gas flow rate at inlet and outlet of single cell, the gas temperature and dew point temperature at inlet of single cell, the current and total voltage as well as in-plane temperature distribution in single cell are measured. The relationship among these data is investigated and the factor causing uneven in-plane temperature distribution is identified. 
Furthermore, the ways to control power generation operation as well as to design the single cell structure in order to enhance the power generation performance and durability of PEFC are proposed.

\section{Nomenclature}

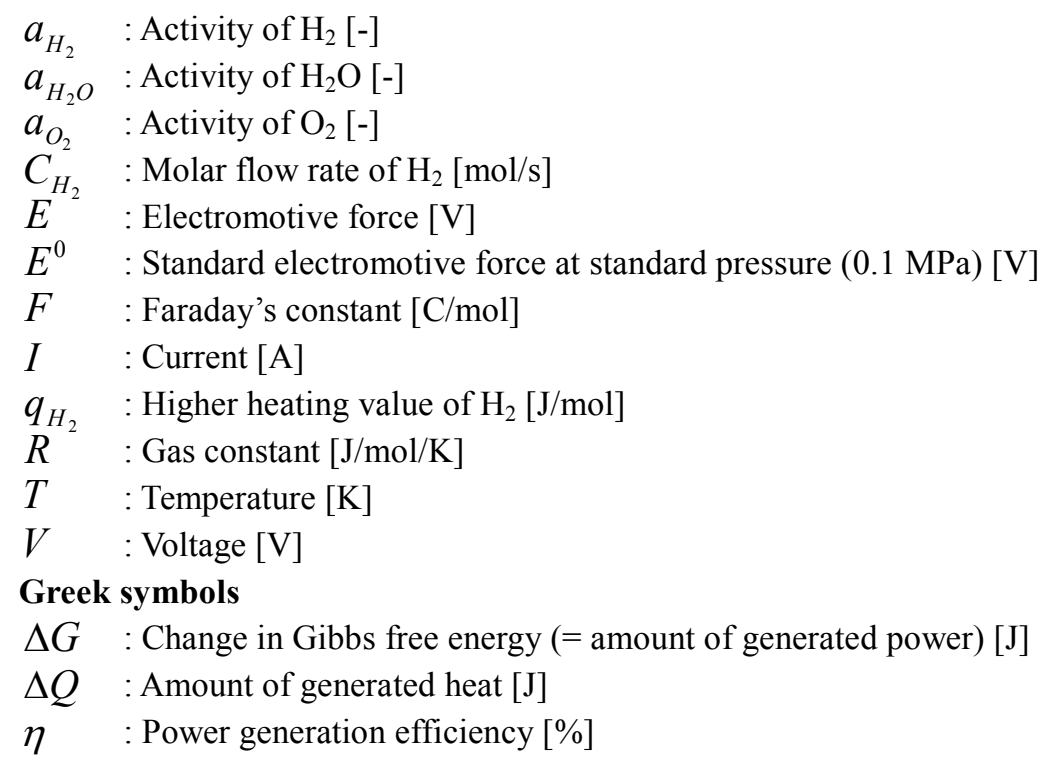

\section{Measurement Procedure of In-plane Temperature Distribution by}

\section{Thermograph}

\subsection{Emissivity of Observation Area}

To measure the temperature by thermograph, presetting the emissivity of object to be measured is necessary. Therefore, the pre-experiment to measure the emissivity of separator was carried out first. In this pre-experiment, the surface temperature at backside of separator whose opposite side was heated uniformly by an electrical hot plate was measured by thermocouple (K-type, CHINO) of diameter of $0.1 \mathrm{~mm}$ and thermograph (TH9100WL, NEC Avio Infrared Ray Technologies) at the same time. The temperature measurement by thermocouple was carried out at four points on the surface of backside of separator. The temperature measurement by thermograph was carried out by presetting the assumed emissivity. By adjusting the preset assumed emissivity and matching these two temperatures, i.e., measured by thermocouple and thermograph, the appropriate emissivity was obtained. The separator used in this study is made from a carbon graphite whose emissivity is generally known from 0.70 to $0.80^{(36,37)}$. However, the black body tape (HB-250, OPTIX) of thickness of $0.1 \mathrm{~mm}$ that was fitted on the surface of backside of separator in the experiment to avoid the uneven in-plane emissivity distribution caused by surface roughness and reflection of backside of separator might affect this value.

Figure 2 shows the relationship between temperature measured by thermocouple and error temperature. In this figure, the error temperature is obtained by subtracting the temperature measured by thermocouple from the temperature measured by thermograph. Changing the assumed emissivity from 0.93 to 0.97 in the pre-experiment, it reveals that the error temperature for the emissivity of 0.95 is the minimum in the temperature range around $343 \mathrm{~K}$ which is the initial temperature of single cell in power generation experiment. Consequently, the emissivity of observation area was decided to be at 0.95 for this study. 
- Emissivity: $0.93 \backsim$ Emissivity: $0.94 \triangle$ Emissivity: 0.95 • Emissivity: 0.96

- Emissivity: 0.97

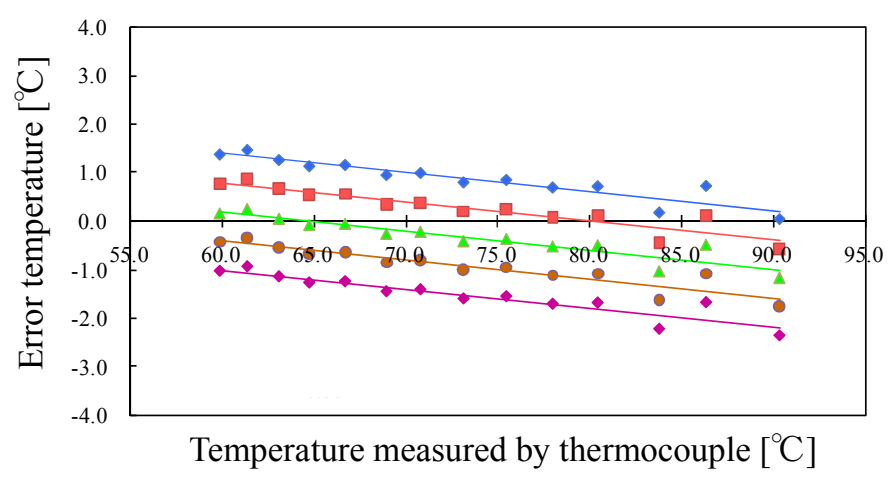

Fig.2 Calibration of emissivity for temperature measurement by thermograph

\subsection{Observation Window}

In this study, a window was made for the single cell of PEFC to measure the in-plane temperature distribution in the cell. The end block, the current collector and the hot water passage plate at cathode of single cell were holed, resulting that the backside of separator to gas channel contacting GDL at cathode can be observed for the measurement of in-plane temperature distribution. Since a glass window was not installed between GDL and separator or MEA at this side, GDL and reaction surface area were not exposed to the atmosphere. The in-plane temperature distribution could then be measured accurately without the influences of gas leak, absorbing infrared rays by water droplet, and tightening pressure of glass window. The size of the observation window, which was equal to that of electrode, was $50 \mathrm{~mm}$ by $50 \mathrm{~mm}$. To prevent gas leak, the width and height of the hole made through the water passage plate was set at $40 \mathrm{~mm}$ and $50 \mathrm{~mm}$, respectively.

\section{Experimental Procedure}

\subsection{Experimental System for Power Generation}

Figure 3 illustrates the experimental system for power generation. Tables 1 and 2 list the specifications of components of the single cell of PEFC and the comparison of structure among different separators used in this study, respectively. The supply gas at anode and cathode, whose pressure and flow rate were controlled by mass flow controller (5850E, BROOKS INSTRUMENT) and valve, was $\mathrm{H}_{2}$ of purity of $99.99995 \%$ and $\mathrm{O}_{2}$ of purity of $99.99995 \%$, respectively. $\mathrm{H}_{2}$ and $\mathrm{O}_{2}$ were supplied by gas cylinders. The relative humidity of supply gas was controlled by a humidifier tank and a dew point meter (HMT337FC, VAISALA) before supplying to the cell. The commercially available single cell of PEFC (MC-25-SC-NH, Micro Cell Technologies) which consisted of MEA, GDL, separator, hot water passage plate, current collector and end block was used in this study. To prevent gas leak, the hot water passage plate, which was inserted into the cell for the temperature management originally, was still installed, but without flowing hot or cold water.

The gas channel pitch of separator (customized by Bit Tech) is changed by $0.5 \mathrm{~mm}, 1.0$ $\mathrm{mm}$ and $2.5 \mathrm{~mm}$. As listed in Table 2, the gas channel depth, the total area of power generation area occupied by gas channel width, the total area of power generation area occupied by rib width, and the power generation area are remained the same among these separators. It is expected that the decrease in gas channel pitch leads to the following phenomena change in the cell of PEFC:

(1) Gas diffuses through GDL more sufficiently and uniformly. 
(2) Pressure drop between inlet and outlet of gas channel of separator is increased due to reduction of cross sectional area of gas channel.

(3) Water droplet which springs from GDL to gas channel is discharged more easily due to increase in pressure drop between inlet and outlet of gas channel of separator.

(4) Water droplet in GDL under rib of separator can be discharged more easily.

(5) PEM is humidified well since pre-humidified gas diffuses through GDL more sufficiently and uniformly.

(6) The power generation performance is promoted since the even in-plane distribution of temperature and current is obtained by uniform gas supply to the reaction surface of cell.

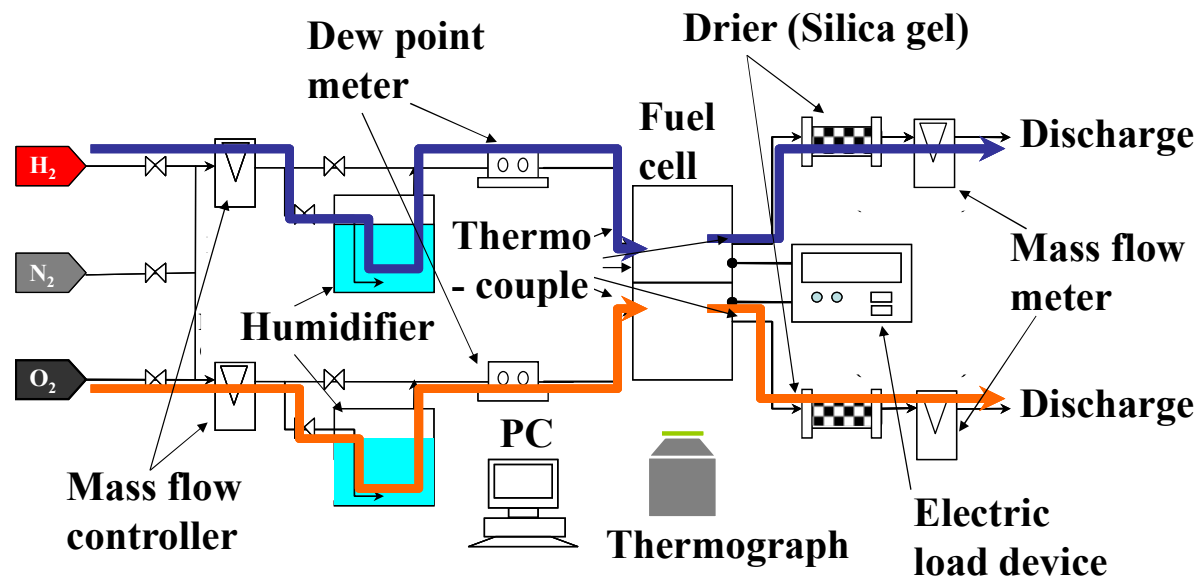

Fig.3 Schematic drawing of experimental system

Table 1 Specification of components of single cell of PEFC

\begin{tabular}{|c|c|c|}
\hline Parts & Size & Characteristics \\
\hline $\begin{array}{l}\text { Polymer } \\
\text { electrolyte } \\
\text { membrane } \\
\text { (PEM) }\end{array}$ & $50.0 \mathrm{~mm} \times 50.0 \mathrm{~mm} \times 0.13 \mathrm{~mm}$ & $\begin{array}{c}\text { Nafion } 115 \\
\text { (produced by } \\
\text { Du Pont Corp.) }\end{array}$ \\
\hline Catalyst & $\begin{array}{c}50.0 \mathrm{~mm} \times 50.0 \mathrm{~mm} \\
\text { (attached with PEM) }\end{array}$ & $\mathrm{Pt} / \mathrm{C}$ (20wt\% Pt loading) \\
\hline $\begin{array}{c}\text { Gas diffusion layer } \\
\text { (GDL) }\end{array}$ & $50.0 \mathrm{~mm} \times 50.0 \mathrm{~mm} \times 0.17 \mathrm{~mm}$ & $\begin{array}{c}\text { Carbon paper } \\
\text { (TGP-H-060 produced by } \\
\text { Toray Corp.) }\end{array}$ \\
\hline Separator & $\begin{array}{c}75.4 \mathrm{~mm} \times 75.4 \mathrm{~mm} \times 2.00 \mathrm{~mm} \\
(\text { Gas supply area: } \\
50.0 \mathrm{~mm} \times 50.0 \mathrm{~mm})\end{array}$ & $\begin{array}{l}\text { Carbon graphite, } \\
\text { Serpentine }\end{array}$ \\
\hline Current collector & $\begin{array}{c}\text { Area: } 6937 \mathrm{~mm}^{2}, \\
\text { Thickness: } 2.00 \mathrm{~mm}\end{array}$ & Copper coated with gold \\
\hline End block & $110 \mathrm{~mm} \times 110 \mathrm{~mm} \times 12.7 \mathrm{~mm}$ & Aluminum \\
\hline
\end{tabular}


Table 2 Comparison of structure among different separators used in this study

\begin{tabular}{|c|c|c|c|}
\hline Number of gas channel [-] & 10 & 5 & 2 \\
\hline $\begin{array}{c}\text { Gas channel pitch [mm] } \\
\text { (Gas channel width : Rib width) }\end{array}$ & $\begin{array}{c}0.5 \\
(1: 1)\end{array}$ & $\begin{array}{c}1.0 \\
(1: 1)\end{array}$ & $\begin{array}{c}2.5 \\
(1: 1)\end{array}$ \\
\hline Gas channel depth $[\mathrm{mm}]$ & \multicolumn{3}{|c|}{1.0} \\
\hline Gas channel pattern & \multicolumn{3}{|c|}{ Serpentine type } \\
\hline $\begin{array}{c}\text { Total area of power generation area } \\
\text { occupied by gas channel width }\left[\mathrm{mm}^{2}\right] \\
\text { (Ratio to the area of gas channel pitch of } 1.0 \mathrm{~mm} \text { ) }\end{array}$ & $\begin{array}{l}1300 \\
(1.00)\end{array}$ & $\begin{array}{l}1300 \\
(1.00)\end{array}$ & $\begin{array}{c}1313 \\
(1.01)\end{array}$ \\
\hline $\begin{array}{l}\text { Total area of power generation area } \\
\text { occupied by rib width }\left[\mathrm{mm}^{2}\right] \\
\text { (Ratio to the area of gas channel pitch of } 1.0 \mathrm{~mm} \text { ) }\end{array}$ & $\begin{array}{c}1200 \\
(1.00)\end{array}$ & $\begin{array}{l}1200 \\
(1.00)\end{array}$ & $\begin{array}{l}1188 \\
(0.99)\end{array}$ \\
\hline $\begin{array}{l}\text { Power generation area }\left[\mathrm{mm}^{2}\right] \\
\text { (Total area of gas channel width } \\
+ \text { total area of rib width) }\end{array}$ & \multicolumn{3}{|c|}{2500} \\
\hline
\end{tabular}

All sides of the cell, other than observation window side and the opposite side to observation window were thermally insulated. The observation area was exposed to the atmosphere. However, the overall heat transfer phenomena in the cell was dominated by heat transfer in PEM, GDL and separator since their thermal conductivity was smaller than that of hot water passage plate, current collector and end block by single- or double-digit. The gas temperature and dew point temperature at inlet was measured using thermocouple (K-type, CHINO) of $0.1 \mathrm{~mm}$ diameter and dew point meter, respectively. The pipes connected to inlet and outlet of the cell were thermally insulated to prevent the heat loss.

The images of in-plane temperature distribution measured by thermograph were recorded and analyzed by the software (TH91-702, NEC Avio Infrared Ray Technologies). The gas flow rate at inlet and outlet of single cell, the gas temperature and dew point temperature at inlet of single cell, the current and total voltage were recorded and analyzed by the software (CISAS, CHINO). The gas flow rate at outlet of single cell was measured by mass flow meter (MODEL8300, KOFLOC) after the gas passed through the drier to protect the mass flow meter. Finally, after the vapor absorption by water tank, the anode gas and the cathode gas were exhausted to the atmosphere.

\subsection{Experimental Procedure}

The single cell was heated up by electrical cloth heater covering the both sides of cell before power generation experiment. The initial temperature of the cell before each experiment was $343 \mathrm{~K}$. The dew point temperature of supply gas at inlet of the cell was $338 \mathrm{~K}$. The absolute pressure of supply gas at inlet of the cell was $0.4 \mathrm{MPa}$ which was the pressure at the regulator of gas cylinder of $\mathrm{H}_{2}$ and $\mathrm{O}_{2}$ since the pressure drop from gas cylinder to the cell was regarded as a little. The in-plan temperature distribution measurement by thermograph was carried out under the current density of $0.80 \mathrm{~A} / \mathrm{cm}^{2}$ which could maintain power generation without external heat supply. Since the gas flow rate at inlet of the cell affected the power generation performance and the in-plane temperature distribution, the impact of gas flow rate at inlet of the cell on the power generation performance and the in-plane temperature distribution was investigated for the different gas channel pitches. Table 3 lists the experimental condition on gas flow rate at 
inlet of the cell. In this table, Experiment I, II, III and IV is the normal operation, the excess gas supply operation, the stoichiometric ratio of 1.00 operation and the shortage gas supply operation, respectively. The gas flow rate at inlet and outlet of the cell, the gas temperature and dew point temperature at inlet of the cell, the initial temperature of the cell, the current and total voltage as well as in-plane temperature distribution in single cell were measured at the same time for every power generation experiment. In this study, the data excluding the shortage gas supply operation condition were obtained after confirming the steady state during about $30-40 \mathrm{~min}$.

Table 3 Experimental condition on gas flow rate at inlet of PEFC

\begin{tabular}{|c|l|c|c|c|c|}
\hline \multicolumn{2}{|c|}{ Experiment } & I & II & III & IV \\
\hline \multirow{2}{*}{ Anode } & $\begin{array}{l}\text { Gas flow rate } \\
\text { at inlet [NL/min] }\end{array}$ & 0.199 & $0.280-0.420$ & 0.140 & 0.126 \\
\cline { 2 - 6 } & $\begin{array}{l}\text { Stoichiometric } \\
\text { ratio [-] }\end{array}$ & 1.43 & $2.00-3.00$ & 1.00 & 0.90 \\
\hline \multirow{2}{*}{ Cathode } & $\begin{array}{l}\text { Gas flow rate } \\
\text { at inlet [NL/min] }\end{array}$ & 0.174 & $0.140-0.210$ & 0.070 & 0.063 \\
\cline { 2 - 6 } & $\begin{array}{l}\text { Stoichiometric } \\
\text { ratio [-] }\end{array}$ & 2.50 & $2.00-3.00$ & 1.00 & 0.90 \\
\hline
\end{tabular}

\section{Experimental Results}

\subsection{Verification on Impact of Observation Window on Power Generation Performance}

To verify the impact of observation window on power generation performance, the power generation experiment with and without observation window was carried out, and the power generation performances of them were compared.

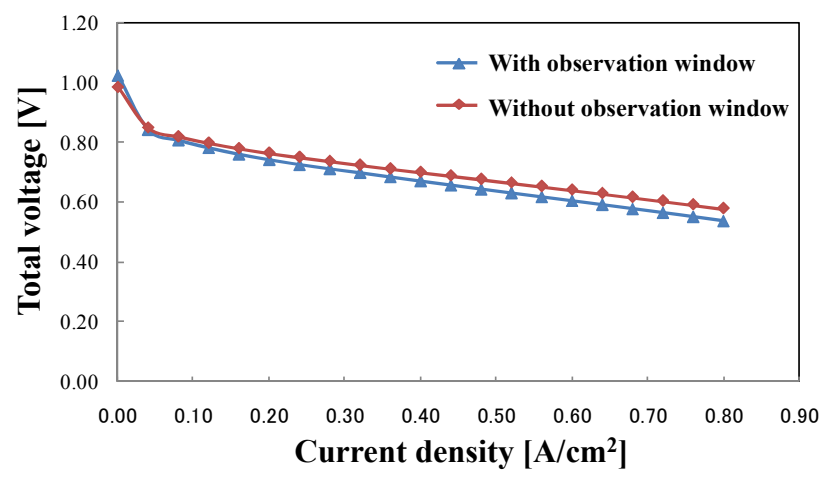

Fig.4 Polarization curves under power generation with and without observation window (gas channel pitch: $1.0 \mathrm{~mm}$ )

Figure 4 shows the polarization curves for the gas channel pitch of $1.0 \mathrm{~mm}$ under power generation with and without observation window. From this figure, it is seen that the total voltage with observation window is smaller than the total voltage without observation window, especially for the higher current density condition. However, the difference between the total voltage with and without observation window is small, which is only $6.8 \%$ for the current density of $0.80 \mathrm{~A} / \mathrm{cm}^{2}$. The decline of power for the current density of $0.80 \mathrm{~A} / \mathrm{cm}^{2}$ by making the observation window is $0.82 \mathrm{~W}$, which is quite smaller than the power without observation window of $12 \mathrm{~W}$ or the enthalpy change of supplied $\mathrm{H}_{2}$ for the oxidization reaction of $29.6 \mathrm{~W}$. Consequently, the impact of observation window on power generation performance can be neglected. 


\subsection{Normal Operation}

Figure 5 shows the images of in-plane temperature distribution for the gas channel pitch of $0.5 \mathrm{~mm}, 1.0 \mathrm{~mm}$ and $2.5 \mathrm{~mm}$ under the normal operation conditions. Although the corners of top right and bottom left in the images are seen black, the cause of it is the insulators covering the pipes connected to inlet and outlet of the cell at cathode. However, as the insulators did not touch and cover the observation area directly, the impact of insulators on the in-plane distribution of temperature could be neglected. The image of in-plane temperature distribution for the gas channel pitch of $1.0 \mathrm{~mm}$ under open circuit voltage (OCV) operation condition is also shown in this figure. Since the power was not generated under OCV operation condition without external heat supply, the cell was heated by the electrical cloth heater covering all sides of the cell other than observation window side and the opposite side to observation window.

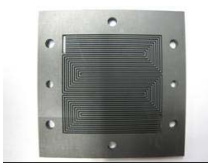

$0.5 \mathrm{~mm}$

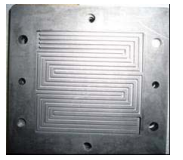

$1.0 \mathrm{~mm}$

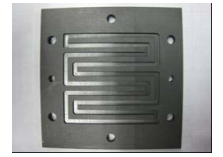

$2.5 \mathrm{~mm}$

Gas channel structure of separator (Opposite side to observation window)

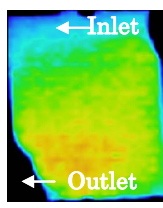

$0.5 \mathrm{~mm}$

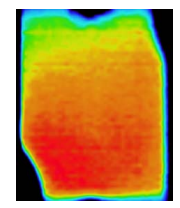

$1.0 \mathrm{~mm}$

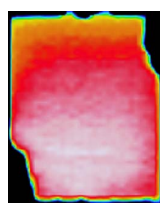

$2.5 \mathrm{~mm}$

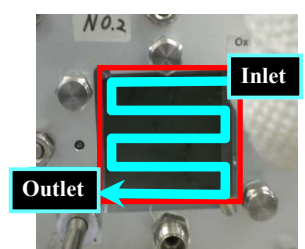

Observation window

(Gas flow pattern)

Fig.5 In-plane temperature distribution under the normal operation condition $\left(\mathrm{OCV}\right.$, current density $\left.=0.80 \mathrm{~A} / \mathrm{cm}^{2}\right)$

According to Fig.5, the temperatures for the current density of $0.80 \mathrm{~A} / \mathrm{cm}^{2}$ are higher than the initial temperature of cell of $343 \mathrm{~K}$ regardless of gas channel pitch compared with the temperatures under OCV operation condition. Since the power can be generated for the current density of $0.80 \mathrm{~A} / \mathrm{cm}^{2}$ without external heat supply, it can conclude that the in-plane temperature distribution caused by the reaction heat is obtained.

From this figure, the temperature around the outlet of cell is higher than the temperature around the inlet of cell for the current density of $0.80 \mathrm{~A} / \mathrm{cm}^{2}$ by about $2 \mathrm{~K}$ regardless of gas channel pitch. The gas flowing through the gas channel in separator is heated by reaction heat through the convection, resulting that the gas temperature downstream along gas channel in separator becomes higher. Therefore, the temperature around the outlet of cell in observation area is higher than the temperature around the inlet of cell in observation area.

Moreover, according to Fig.5, it is known that the temperature range in observation area is dropped with decreasing gas channel pitch for the current density of $0.80 \mathrm{~A} / \mathrm{cm}^{2}$. However, the total voltage is increased with decreasing gas channel pitch. The total voltage of gas channel pitch of $0.5 \mathrm{~mm}, 1.0 \mathrm{~mm}$ and $2.5 \mathrm{~mm}$ for the current density of 0.80 $\mathrm{A} / \mathrm{cm}^{2}$ under the normal operation condition is $0.55 \mathrm{~V}, 0.52 \mathrm{~V}$ and $0.50 \mathrm{~V}$, respectively. As expected, the power generation performance is promoted since the gas is supplied to the reaction surface uniformly due to the decrease in gas channel pitch. According to the energy conservation equation, $\Delta Q$ is decreased with increasing $\Delta G$, that is, increasing total 
voltage under the constant current density ${ }^{(7)}$. Consequently, with decreasing gas channel pitch, the temperature range in observation area is dropped but total voltage is increased.

\subsection{Excess Gas Supply Operation}

Figure 6 shows the images of in-plane temperature distribution for the gas channel pitch of $0.5 \mathrm{~mm}, 1.0 \mathrm{~mm}$ and $2.5 \mathrm{~mm}$ under the excess gas supply operation conditions. Table 4 lists the obtained data on gas flow rate and total voltage under the excess gas supply condition.

$<$ Stoichiometric ratio : $2.00>$

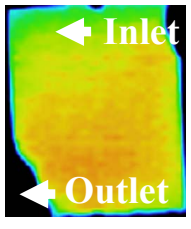

$0.5 \mathrm{~mm}$

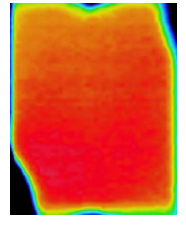

$1.0 \mathrm{~mm}$

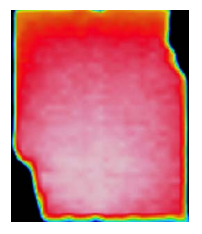

$2.5 \mathrm{~mm}$

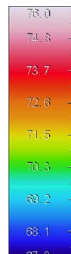

$<$ Stoichiometric ratio : $3.00>$

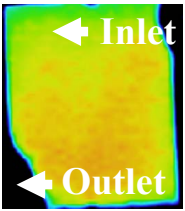

$0.5 \mathrm{~mm}$

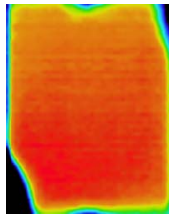

$1.0 \mathrm{~mm}$

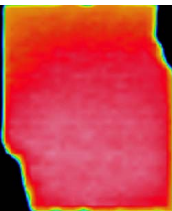

$2.5 \mathrm{~mm}$
340

$349 \mathrm{~K}$

344.5

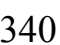

$349 \mathrm{~K}$

339

Fig.6 In-plane temperature distribution under the excess gas supply operation condition

According to Fig.6, the temperature around the outlet of cell is higher than the temperature around the inlet of cell by about $2 \mathrm{~K}$ regardless of gas channel pitch. This result is same as the result under the normal operation condition. Since the stoichiometric ratio of gas flow at anode and cathode is 1.43 and 2.50, respectively, the normal operation condition is actually also an excess gas supply operation condition. From Fig.6, it can be seen that the temperature in observation area is dropped by about $1.0 \mathrm{~K}$ with increased gas flow from the stoichiometric ratio of 2.00 to that of 3.00. Due to increase in the supply gas which is colder than reaction surface to the cell, the cooling effect by convection became bigger for not only observation area but also GDL and reaction surface.

According to Table 4, the total voltage and the consumed gas flow rate, which is estimated by subtracting gas flow rate at outlet of cell from the gas flow rate at inlet of cell, for the stoichiometric ratio of 2.00 are almost same as those for the stoichiometric ratio of 3.00 regardless of gas channel pitch. Since the consumed gas flow rate is constant for these conditions, the unconsumed gas flow rate is increased with increased stoichiometric ratio of gas flow at inlet of cell. Therefore, the cooling effect due to convection by unconsumed gas flow is bigger. In addition, the total voltage is increased with decreasing gas channel pitch, which is similar to the result under the normal operation condition. 
Table 4 Comparison of gas flow rate and total voltage among separators used in this study under the excess gas supply operation condition

\begin{tabular}{|c|c|c|c|c|c|c|}
\hline $\begin{array}{c}\text { Gas } \\
\text { channel } \\
\text { pitch } \\
{[\mathrm{mm}]}\end{array}$ & $\begin{array}{c}\text { Stoichiometric } \\
\text { ratio } \\
{[-]}\end{array}$ & \multicolumn{2}{|c|}{$\begin{array}{c}\text { Gas flow rate } \\
\text { at inlet } \\
{[\mathrm{NL} / \mathrm{min}]}\end{array}$} & \multicolumn{2}{c|}{$\begin{array}{c}\text { Gas flow rate } \\
\text { at outlet } \\
{[\mathrm{NL} / \mathrm{min}]}\end{array}$} & \multirow{2}{*}{$\begin{array}{c}\text { Total } \\
\text { voltage } \\
{[\mathrm{V}]}\end{array}$} \\
\cline { 3 - 6 } & & Anode & Cathode & Anode & Cathode & \\
\hline \multirow{2}{*}{0.5} & 2.00 & 0.280 & 0.140 & 0.125 & 0.066 & 0.55 \\
\cline { 2 - 6 } & 3.00 & 0.420 & 0.210 & 0.274 & 0.143 & 0.55 \\
\hline \multirow{2}{*}{1.0} & 2.00 & 0.280 & 0.140 & 0.123 & 0.065 & 0.52 \\
\cline { 2 - 6 } & 3.00 & 0.420 & 0.210 & 0.271 & 0.142 & 0.53 \\
\hline \multirow{2}{*}{2.5} & 2.00 & 0.280 & 0.140 & 0.124 & 0.065 & 0.50 \\
\cline { 2 - 6 } & 3.00 & 0.420 & 0.210 & 0.274 & 0.143 & 0.50 \\
\hline
\end{tabular}

\subsection{Stoichiometric Ratio of 1.00 Operation}

Figure 7 shows the images of in-plane temperature distribution for the gas channel pitch of $0.5 \mathrm{~mm}, 1.0 \mathrm{~mm}$ and $2.5 \mathrm{~mm}$ under the stoichiometric ratio of 1.00 operation condition. Table 5 lists the obtained data on gas flow rate and total voltage under the stoichiometric ratio of 1.00 operation condition. The steady state for the stoichiometric ratio of 1.00 operation was confirmed under the experimental condition of this study though the power generation stop by condensed water was afraid. Since the pressure of supply gas at inlet of the cell which was $0.4 \mathrm{MPa}$ was high, it is thought to be easy to discharge the water from the cell. According to Fig.7, it can be seen that the in-plane temperature distribution is quite even regardless of gas channel pitch. Compared with Figs. 5 and 6, the in-plane temperature distribution in Fi.g7 is more even.

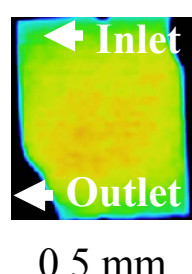

$0.5 \mathrm{~mm}$

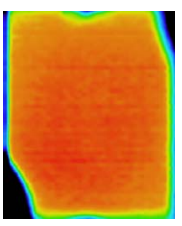

$1.0 \mathrm{~mm}$

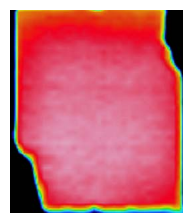

$2.5 \mathrm{~mm}$

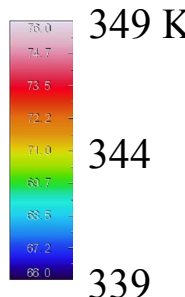

Fig.7 In-plane temperature distribution under the stoichiometric ratio of 1.00 operation condition

Table 5 Comparison of gas flow rate and total voltage among separators used in this study under the stoichiometric ratio of 1.00 operation condition

\begin{tabular}{|c|c|c|c|c|c|c|c|}
\hline $\begin{array}{c}\text { Gas } \\
\text { channel } \\
\text { pitch } \\
{[\mathrm{mm}]}\end{array}$ & \multicolumn{2}{|c|}{$\begin{array}{c}\text { Stoichiometric } \\
\text { ratio } \\
{[-]}\end{array}$} & \multicolumn{2}{|c|}{$\begin{array}{c}\text { Gas flow rate } \\
\text { at inlet } \\
{[\mathrm{NL} / \mathrm{min}]}\end{array}$} & \multicolumn{2}{|c|}{$\begin{array}{c}\text { Gas flow rate } \\
\text { at outlet } \\
{[\mathrm{NL} / \mathrm{min}]}\end{array}$} & $\begin{array}{c}\text { Total } \\
\text { voltage } \\
{[\mathrm{V}]}\end{array}$ \\
\cline { 2 - 7 } & Anode & Cathode & Anode & Cathode & Anode & Cathode & \\
\hline 0.5 & 1.00 & 1.00 & 0.140 & 0.070 & 0.000 & 0.000 & 0.56 \\
\hline 1.0 & 1.00 & 1.00 & 0.140 & 0.070 & 0.000 & 0.000 & 0.52 \\
\hline 2.5 & 1.00 & 1.00 & 0.140 & 0.070 & 0.000 & 0.000 & 0.51 \\
\hline
\end{tabular}

From Table 5, the gas supplied to the cell is consumed completely regardless of gas channel pitch, resulting that the effect of convective heat transfer by unconsumed gas flow on in-plane temperature distribution on observation area became less. At the same time, 
total voltage is increased with decreasing gas channel pitch for the stoichiometric ratio of 1.00 operation condition. The total voltages listed in Table 5 are almost same as those under the normal or excess gas supply operation condition. Consequently, the even in-plane temperature distribution and high power generation performance are achieved under the stoichiometric ratio of 1.00 operation condition though this conclusion is confirmed under the limited condition like pure $\mathrm{O}_{2}$ supply condition.

From this result, it reveals that the power can be generated without excess supply of $\mathrm{H}_{2}$ and $\mathrm{O}_{2}$, although the excess gas supply operation is generally selected as an operation condition of PEFC. If the power generation system of PEFC is operated under the stoichiometric ratio of 1.00 operation condition, the following merits are expected: (1) the reduction of power for blower, gas cylinder or pump due to decreased mass flow of supply gas, and (2) the reduction of pipes and equipment to recover or reutilize the unconsumed gas which is exhausted from the cell. They lead to the save of energy and costs for the whole system of PEFC. It is thought that this simple operation management for promotion of power generation performance is very novel and effective for operating PEFC efficiently.

\subsection{Shortage Gas Supply Operation}

Figure 8 shows the images of in-plane temperature distribution for the gas channel pitch of $0.5 \mathrm{~mm}, 1.0 \mathrm{~mm}$ and $2.5 \mathrm{~mm}$ under the deficient gas supply operation condition. Under this condition, the power generation could not last and was stopped within 5 minutes regardless of gas channel pitch after the ratio of gas flow at inlet of cell was changed from stoichiometric 1.00 to 0.90 . The images of in-plane temperature distribution, which was taken by every $30 \mathrm{sec}$ after setting the ratio of gas flow at inlet of cell to 0.90 , are shown in Fig.8. From this figure, it can be seen that the temperature around the inlet of cell is raised with passing time regardless of gas channel pitch. Since the amount of supply gas is not enough, the power is not generated in the latter area of separator. Without power generation, the temperature of latter area of separator is dropped, resulting that the temperature around the inlet of cell is seen relatively higher compared with the temperature around the outlet of cell.

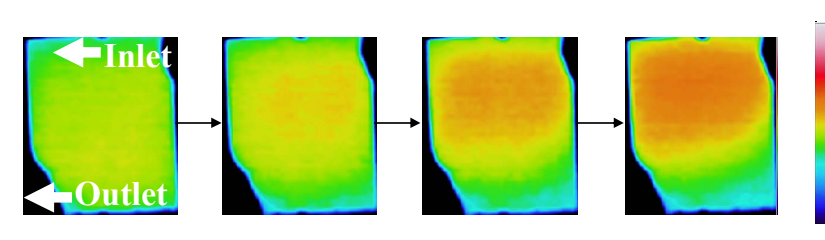

$0.5 \mathrm{~mm}$
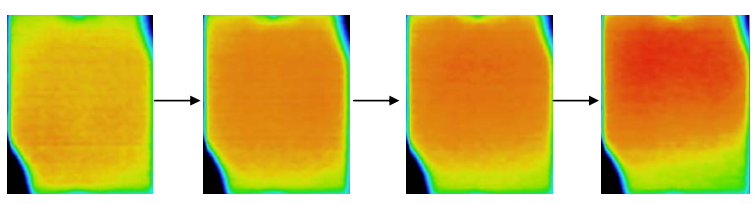

$1.0 \mathrm{~mm}$
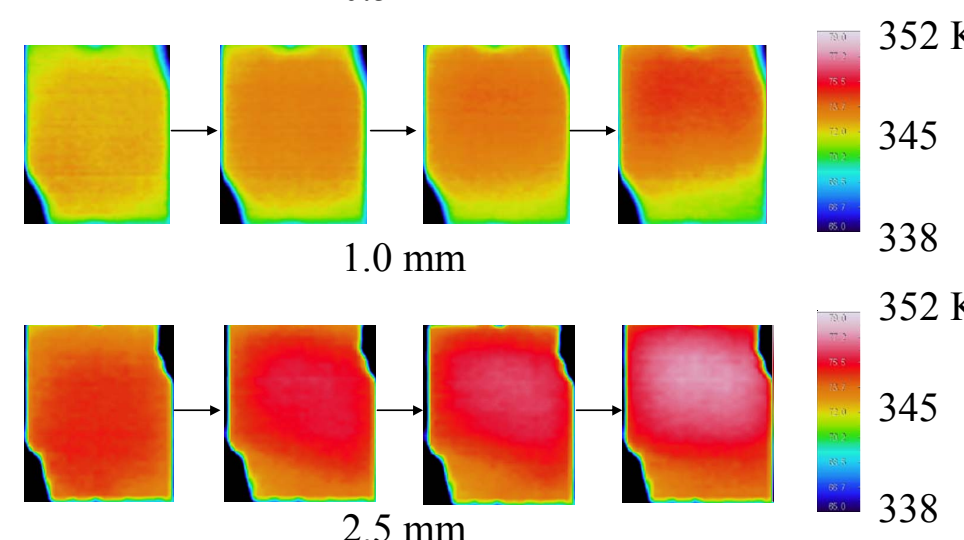

Fig.8 In-plane temperature distribution under the shortage gas supply operation condition 


\section{Proposal for High Power Generation Performance and Durability} Enhancement of PEFC

The ways for better operation and design of the PEFC are investigated based on the above results and discussions.

The gas flow rate affects the in-plane temperature distribution and power generation performance of cell significantly. If the ratio of supplied $\mathrm{O}_{2}$ at inlet of cell at cathode is set over the stoichiometric ratio of 1.00 , the excess gas is heated up by reaction heat through convection. The gas temperature in gas channel becomes higher as the gas is carried to the downstream in separator, resulting that the temperature around the outlet of cell is higher than the temperature around the inlet of cell. In addition, the gas flow rate in gas channel is higher with decreasing gas channel pitch, resulting that the impact of convection heat transfer between the gas channel in separator and GDL or the rib in separator becomes larger. Therefore, it can be thought that the cooling effect by the convection heat transfer is increased for the narrower gas channel pitch. The experiment reveals that the high power generation performance and even in-plane temperature distribution are obtained under the stoichiometric ratio of 1.00 operation condition for both $\mathrm{H}_{2}$ and $\mathrm{O}_{2}$ in this study. Therefore, it is possible that high power generation performance and save of energy and costs of PEFC are realized at the same time if the even in-plane temperature distribution and the uniform gas supply in the cell are attained by supplying gas at the stoichiometric ratio of 1.00 , though the applicable operation condition is limited to $\mathrm{O}_{2}$ supply condition investigated in this study. In other words, the excess gas ratio is not required.

Regarding gas channel pitch, the in-plane distribution of gas concentration is more even with decreased gas channel pitch, resulting in enhancement of power generation performance. Due to enhancement of the conversion efficiency from chemical energy of $\mathrm{H}_{2}$ to electrical energy, the temperature in observation area is dropped with decreased gas channel pitch.

In this study, the power generation efficiency for the gas channel pitch of $0.5 \mathrm{~mm}, 1.0$ $\mathrm{mm}$ and $2.5 \mathrm{~mm}$ under the stoichiometric ratio of 1.00 operation condition is $37.6 \%$, $35.3 \%$ and $34.4 \%$, respectively. The power generation efficiency, which considers the performance of single cell only, is calculated by the following equation:

$$
\eta=\frac{I \times V}{C_{H_{2}} \times q_{H_{2}}} \times 100
$$

where $C_{\mathrm{H}_{2}}$ is obtained by dividing the current of $20 \mathrm{~A}$ by Faraday Constant of 96500 $\mathrm{C} / \mathrm{mol}$ and valence of $\mathrm{H}_{2}$ ion of 2. $q_{\mathrm{H}_{2}}$ is the higher heating value of $\mathrm{H}_{2}$ of $285.8 \mathrm{~kJ} / \mathrm{mol}$.

The maximum power generation efficiency of $37.6 \%$ obtained in this study exceeds the goal of $36 \%$ for developing the stationary PEFC by 2030 in Japan ${ }^{(38)}$, though this goal is set for the whole system of PEFC including supply gas production and components such as gas pump. Although the development way from single cell to the whole system should be considered, it validated that the enhancement of power generation performance of PEFC by simple improvement of separator structure and optimization of power generation operation condition is very effective.

\section{Conclusion}

The in-situ measurement of in-plane temperature distribution in the single cell of PEFC under power generation has been carried out by thermograph through an observation window for customized separators which have different gas channel pitches under several 
gas supply conditions. The following conclusions have been obtained:

(1) If the excess ratio of gas flow at inlet is applied, uneven temperature cross the cell will be resulted. In other words, the temperature around the outlet of cell in observation area will be higher than the temperature around the inlet of cell due to convective heat transfer by the excess $\mathrm{O}_{2}$ which is unconsumed by reaction flowing through the gas channel of separator.

(2) If the stoichiometric ratio of 1.00 , i.e., no excess gas supply at the inlet at anode and cathode is set, the in-plane temperature distribution in observation area will be even, resulting in the higher power generation performance. Under this operation condition, it reveals that the save of energy and costs for the whole system of PEFC and the high power generation performance of PEFC can be realized at the same time.

(3) With decreasing gas channel pitch, the temperature range in observation area is dropped while the total voltage generated is increased. These are confirmed regardless of gas supply condition.

(4) Since the in-plane distributions of gas concentration and temperature becomes more even by decreasing gas channel pitch, the power generation performance of the PEFC is enhanced. The maximum power generation efficiency of $37.6 \%$ is achieved for the gas channel pitch of $0.5 \mathrm{~mm}$ under the stoichiometric ratio of 1.00 operation condition.

\section{Acknowledgements}

The authors are grateful for the support from Mie prefecture industrial research institute for this study.

\section{References}

(1) Ogawa, T., Chikahisa, T. and Kikuta, K., Measurement of Fluctuating Distribution in PEFC due to Produced Water, Preprints of Thermal Engineering Conference 2003, No.03-30 (2003-11), pp.483-484.

(2) Rulliere, R., Lefevre, F. and Lallemand, M., Prediction of the Maximum Heat Transfer Capability of Two-Phase Heat Spreaders -Experimental Validation-, International Journal of Heat and Mass Transfer, Vol.50 (2007), pp.1255-1262.

(3) Enami, Y., Analysis on Lateral Distribution in Polymer Electrolyte Fuel Cell, Fuji Times, Vol.75, No.9 (2002), pp.524-526 (in Japanese).

(4) Ito, K., Temperature Distribution Measurement in Through-Plane Direction for PEFC, Journal of Japan Society of Mechanical Engineers, Vol.111, No.1079 (2008), pp.42-44.

(5) Kubo, N., Fukuyama, Y., Mashio, T., Sakamoto, Y., Kusaka, J. and Daisho, Y., Study on Transport Phenomena in Polymer Electrolyte Fuel Cell (First Report) -The Experimental and Numerical Investigation by the Use of Segmented Cell-, Transactions of Society of Automotive Engineers of Japan, Vol.35, No.4 (2004), pp.65-71.

(6) Tanigawa, H., Miyazaki, Y. and Tsuruta, T., Effect of Water Production on the Polymer Electrolyte Fuel Cell Performance, Preprints of the 45th National Heat Transfer Symposium of Japan, A223 (2008-5), pp.445-446.

(7) Wang, M., Guo, H. and Ma, C., Temperature Distribution on the MEA Surface of a PEMFC with Serpentine Channel Flow Bed, Journal of Power Source, Vol.157 (2006), pp.181-187.

(8) Weber, A. Z., Darling, R. M. and Newman, J., Modeling Two-Phase Behavior in PEFC's Journal of Electrochemical Society, Vol.151 (2004), pp.A1715-A1727.

(9) Yokouchi, Y., Ogawa, K., Haishi, T. and Ito, K., Current-Distribution Measurement in Membrane Electrode Assembly under Water Electrolysis Condition Using NMR Sensor, 
Proceedings of 2nd International Forum on Heat Transfer, No.123 (2008-9), p.94.

(10) Tsuji, K., Domestic Fuel Cell Co-Generation System Entering Real Commercial Stage, Hydrogen Energy System, Vol.33 (2008), pp.65-69 (in Japanese).

(11) Uchida, H., Analysis on Degradation Mechanism of Polymer Electrolyte Fuel Cell, Preprints of the NEDO Symposium "Observation on Polymer Electrolyte Fuel Cell for High Performance and High Durability and Priority Subject on Technology Development in Future”, (2008), p.35 (in Japanese).

(12) Nanjo, T., Tsushima, S., Nishida, K., Teranishi, K. and Hirai, S., Lateral Distribution of Water Content in a Polymer Electrolyte Fuel Cell Membrane by Magnetic Resonance Imaging, Preprints of Thermal Engineering Conference 2005, No.05-17 (2005-11), pp.265-266.

(13) Ogawa, T., Hohara, N., Chikahisa, T. and Hishimura, Y., Prospect of Water Production and Temperature Distribution in PEM Fuel Cells, Thermal Science and Engineering, Vol.23 (2004), pp.93-94.

(14) Wang, Y. and Wang, C. Y., A Nonisothermal Two-Phase Model for Polymer Electrolyte Fuel Cells, Journal of Electrochemical Society, Vol.153, No.6 (2006), pp.A1193-A1200.

(15) Fukui, K., Nakayama, H., Tabe, Y., Chikahisa, T., Takahashi, S. and Yoshizawa, K., Cold Start Characteristics and Freezing Phenomena in PEM Fuel Cell below Freezing, Preprints of the 44th National Heat Transfer Symposium of Japan, A159 (2007-5), pp.73-74.

(16) Hasahimoto, K., Tanno, H., Koike, S., Izumi, T. and Ejiri, E., Visualization of Moisture Generation in a Polymer Electrolyte Fuel Cell, Visualization Information, Vo.24, No.1 (2004), pp.129-132 (in Japanese).

(17) Jiao, K., Park, J. and Li, X., Characteristics of Liquid Water Removal from the Gas Diffusion Layer by Reactant Flow in PEM Fuel Cell, Proceedings of the 4th International Green Energy Conference, Paper ID23 (2008), pp.62-73.

(18) Kodaka, T., Tsushima, S. and Hirai, S., Transport Analysis of Generated Water and Water Vapor on Hydration of Polymer Electrolyte Fuel Cell Membrane by Nuclei-labeling MRI, Preprints of the 44th National Heat Transfer Symposium of Japan, C136 (2007-5), pp.221-222.

(19) Konomi, T., Nagata, J. and Murakami, H., Development of High Performance Visualized PEFC for Microscopic Image Analysis, Transactions of the Japan Society of Mechanical Engineers, Series B, Vol.72, No.724 (2006), pp.2978-2983.

(20) Nishida, K., Tsushima, K., Teranishi, K. and Hirai, S., Visualization of Microscopic Behavior and Promotion of Water Removal in a Porous Electrode of Polymer Electrolyte Fuel Cell, Transactions of the Japan Society of Chemical Engineers, Vol.33, No.2 (2007), pp.181-185 (in Japanese).

(21) Ogawa, K., NMR/MRI Measurement -Principle of Measurement and Application to PEFC and Gas-Hydrate, Journal of Heat Transfer Society of Japan, Vol.47, No.200 (2008), pp.27-39.

(22) Tasaki, Y., Ichikawa, Y., Kubo, N. and Shirohara, K., In Situ Diagnostic of Water Distribution in Thickness Direction of MEA by Neutron Imaging -Focused on Characteristics of Water Distribution in Gas Diffusion Layer-, Preprints of the 45th National Heat Transfer Symposium of Japan, I134 (2008-5), pp.385-386.

(23) Tsushima, S., Nanjo, T., Kotaka, T., Yoshida, M. and Hirai, S., Development of Advanced Magnetic Resonance Imaging Techniques for Water Transport Analysis in PEFC, Preprints of Fuel Cell Symposium, (2007), pp.180-183.

(24) Ogawa, T., Nohara, N., Kikuta, K., Chikahisa, T. and Hishimura, Y., Observation of Water Production and Temperature Distribution in PEM Fuel Cells, Preprints of the 41st National Heat Transfer Symposium of Japan, F154 (2004-5), pp.235-236.

(25) Nohara, N., Kikuta, K., Tabe, Y. and Chikahisa, T., Simulations Measurement of Mass and Heat Transfer Phenomena and Current Density Distribution in PEFC, Preprints of the Japan 
Society of Mechanical Engineers, No.05-01(2004-9), pp.273-274.

(26) Ding, Y., Liao, Q., Zhu, X., Li, J., Tian, X., Shi, Y. and Ji, S., Visualization Study on the Cathode Flooding and Two-Phase Flow Resistance Characteristics of a DMFC, Proceedings of the 4th International Green Energy Conference, Paper ID50 (2008), pp.118-133.

(27) Yokoi, Y., Nishida, K., Tsushima, S. and Hirai, S., Visualization Measurement of Water in Anode of PEFC by Water Sensitive Paper, Preprints of the 46th National Heat Transfer Symposium of Japan, B2-225 (2009-6), pp.387-388.

(28) Manabe, S., Uemura, Y., Ohora, K., Araki, T. and Onda, K., Effects of Transport Resistance at MEA Surfaces on PEFC Transient Power Generation, Preprints of the 46th National Heat Transfer Symposium of Japan, B2-311 (2009-6), pp.583-584.

(29) Konomi, T., Kitahara, T., Nakajima, H. and Murakami, H., Analysis of Electric Generation Distribution on PEFC Electrode (1st Report, Electric Generation Distribution under Rib and Gas Channel on $1 \mathrm{~mm}$ Rib Width Cell), Transactions of the Japan Society of Mechanical Engineers, Series B, Vol.73, No.726 (2007), pp.631-637.

(30) Konomi, T., Kitahara, T., Nakajima, H. and Murakami, H., Analysis of Electric Generation Distribution on a PEFC Electrode (2nd Report, Electric Generation Distribution on a PEFC with Ribs and Flow Channels of $2 \mathrm{~mm}$ Width), Transactions of the Japan Society of Mechanical Engineers, Series B, Vol.74, No.739 (2008), pp.678-683.

(31) Konomi, T., Kitahara, T., Nakajima, H. and Takazono, Y., Development of a PEFC with Serpentine Hybrid Gas Channels (1st Report, Design and Performance of the PEFC), Transactions of the Japan Society of Mechanical Engineers, Series B, Vol.75, No.752 (2009), pp.569-576.

(32) Takazono, Y., Konomi, T., Kitahara, T. and Nakajima, H., Development of a PEFC with Serpentine Hybrid Gas Channels (2nd Report, Effects of the Flow Velocity in a Low Pressure Channel), Transactions of the Japan Society of Mechanical Engineers, Series B, Vol.75, No.752 (2009), pp.577-584.

(33) Nguyen, T. V., A Gas Distributor Design for Proton-exchange-membrane Fuel Cells, Journal of the Electrochemical Society, Vol.143, No.5 (1996), pp.L103-L105.

(34) Shudo, T. and Suzuki, K., Performance Improvement in Direct Methanol Fuel Cells Using a Highly Porous Corrosion-Resisting Stainless Steel Flow Field, International Journal of Hydrogen Energy, Vol.33, No.11 (2008), pp.2850-2856.

(35) Morioka, S., Tabe, Y., Kikuta, K., Chikahisa, T. and Kozaki, M., Performance and Internal Phenomena in PEM Fuel Cells with Porous Separator, Preprints of the 46th National Heat Transfer Symposium of Japan, B2-231 (2009-6), pp.597-598.

(36) The Japan Society of Mechanical Engineers ed., Heat Transfer Hand Book, (1993), pp.238-240, Maruzen.

(37) Saito, K., Inorganic Chemistry Book X-2 Boron, Carbon, Germanium, (1965), p.260, Maruzen.

(38) New Energy and Industrial Technology Development Organization (NEDO), "Road Map of PEFC". Home Page of NEDO. (on-line), available from https://app3.infoc.nedo.go.jp/informations/koubo/events/FA/nedoeventpage.2008-06-18.141 4722325/30ed30fc30de30c3PEFC5b9a7f6e7528.pdf (accessed 2009-7-20). 